tection. Narjes, like Davignon a lawyer by training, is regarded as being for nuclear power and, with little in his past to suggest that he will be particularly radical in his approach to environmental issues, his coming is regarded with some apprehension.

Ivor Richard's past experience in the Labour government includes the post of parliamentary under-secretary of state for defence in 1969-70 and deputy spokesman on foreign affairs between 1972 and 1974. $\mathrm{He}$ was the British ambassador to the United Nations from 1974 to 1979. Previously he had been a Council of Europe delegate and, during the same period, 1965-69, had been with the West European Union.

The new commissioners as a whole are largely right-wing men with legal backgrounds. They include nobody with previous experience in scientific affairs. It may be an advantage, however, that Richard, without any other major responsibilities, will be in a position to give his full attention to promoting the interests of his directorates-general. Davignon is certainly keen to increase the Community's influence on the industrial research programmes of the member states. It will clearly be some time before the new Commission settles down and begins to exert an appreciable influence on Community policy; undoubtedly the immediate problems associated with the budget and the form of the Common Agricultural Policy will take precedence for the time being.

Jasper Becker

\section{Nucleotide sequences}

\section{Too many banks?}

The US National Institutes of Health (NIH) and the European Molecular Biology Organization (EMBO) seem well on the way to founding a computerized bank of nucleotide sequences, but wouldbe competitors have not yet withdrawn from the field. The joint NIH/EMBO plan springs from meetings in Bethesda (Maryland) and Heidelberg last year, both of which acknowledge that nucleotide sequencing techniques now in use are likely to generate more information than can be assimilated informally.

For the time being, nucleotide sequences are being collected at EMBO headquarters in Heidelberg by Mr Greg Hamm. Other centres interested in the collection of nucleotide sequences include the George Washington University, Washington DC, where Dr Margaret Dayhoff plans to broaden the scope of her collection of amino acid sequences; the Los Alamos Scientific Laboratory; and Professor Richard Grantham's CNRS Laboratoire de Biometrie at Lyon.

The work now being carried out at Heidelberg is regarded as a necessary preparation for an eventual long-term decision by EMBO and NIH. It is by no means certain that the two institutions will continue to collaborate, although such an arrangement is seen as a potentially valuable precedent. In the meantime, the Heidelberg collection is being compiled and made available informally.

The outstanding technical problems are more concerned with molecular biology than with computer technology. Storing, retrieving and comparing nucleotide sequences stored in computer language can be tackled with existing programs, but decisions have yet to be made about the criteria by which sequences should be considered authentic, while the problems of merging incomplete sequences with each other, and of accommodating and authenticating variations, will entail something like a critical evaluation of data in molecular biology.

The NIH/EMBO plan assumes that nucleotide sequences will eventually be made available to all suitably qualified scientists, but also supposes that the effective management of a sequence repository will require the continuing presence of a small group concerned with the analysis of sequence data.

Professor Richard Grantham's plans are similar. His bank is said to contain all published sequences of more than 150 nucleotides, but IRNA and 5S rRNA sequences are not included because of their variability. At the end of September, the Lyon bank included $200 \mathrm{mRNA}$ sequences together with 10 complete genome sequences and 100 untranslated sequences. A description of the bank and a list of its contents can be had free of charge from Université Lyon 1, 69622 Villeurbanne Cédex, France.

It is hoped that the future of the NIH/EMBO project will be decided early this year, after consultations with other interested parties. One of the potentially contentious issues is that of whether bodies such as EMBO and NIH should centralize an activity recognized to be essential but traditionally left to individual research workers relying on grants from similar bodies.

\section{Polish pollution}

\section{Smelter shuts down}

Poland's new Ecological Society has won a major triumph in its battle to halt pollution in Krakow - a ministerial promise that the Skawina aluminium works, one of Poland's two major producers of the metal, will be closed down entirely. The campaign against the Skawina works has been going on since the society was founded last September.

The post-war industrialization of Krakow, beginning with the building of the giant Lenin steel mills at Nowa Huta, has brought major pollution problems. By the end of the 1970s, Krakow, which lies in a hollow with little natural circulation of air, annually received an estimated 95,000 tonnes of dust and 70,000 tonnes of sulphur dioxide a year from Nowa Huta to the east, and 33,000 tonnes of dust and 33,000 tonnes of sulphur dioxide from the Skawina complex (a coal-fired power station and aluminium plant) to the southwest. Ecologists working on the former Royal Forest of Niepolomice some $20 \mathrm{~km}$ from Krakow had to recommend measures such as aerial spraying with lime to neutralize the acid rain.

Outside the technical journals and reports, little was published on the problem, although the local population could see for themselves the outpourings of smoke (new electrostatic precipitators were constantly being promised) and there were increasing fears of the health hazards of locally grown vegetables. The first real public hint that there was an even greater gas hazard than that of sulphur dioxide came in the autumn of 1979, with the revelation that gold art treasures in the Wawel Castle museum were becoming corroded.

A year later, however, the new Ecological Society, whose membership includes representatives of the "interested public" as well as experts, was demanding a "truthful report" on Krakow's monuments and environment including public health issues. The society's memorandum, published in the Krakow newspaper Gazeta Poludniowa of 20 November, demanded in particular that all processes emitting fluorine and hydrogen fluoride must be shut down until this hazard could be eliminated. In fact, both the Skawina works (the main source of fluorine pollution) and the Nowa Huta steel mill were already scheduled for modernization - at costs of 120 million zloty ( $£ 2$ million) and 7,500 million zloty (£125 million) respectively. Preliminary work on these projects, it was promised, would begin during 1981 .

But the debate continued and was taken up by the national television network. By the end of December, the Minister of Metallurgy, Zbigniew Szalajda, had agreed to a partial cut-back in production, and ordered 35 obsolete electrolysis tubs to be taken out of service. The Mayor of Krakow, Josef Gajewicz, increased the number to 160 , cutting hydrogen fluoride emission by 60 per cent and aluminium production by almost half. On 5 January this year, the minister told the press that Mayor Gajewicz's action would produce a "very difficult situation" for manufacturers requiring aluminium. Ways would have to be found to step up production from Poland's other smelting plant at Konin. The ministry's plans for the future of the Skawina plant, he said, would be outlined shortly. Two days later, after a meeting with community representatives and journalists in Krakow, the minister announced that, "taking into account all the circumstances, the demands of the community and the economic aspects", the plant would be closed and the project "totally abandoned". Vera Rich 